\title{
Bioconversion of Jatropha curcas seed cake to hydrogen by a strain of Enterobacter aerogenes
}

\author{
Sofia Lewis Lopes ${ }^{\mathrm{a}, \mathrm{b}}$, Rita Fragoso ${ }^{\mathrm{b}}$, Elizabeth Duarte ${ }^{\mathrm{b}}$, Paula A.S.S. Marques ${ }^{\mathrm{a}, *}$ \\ ${ }^{a}$ Unidade de Bioenergia, Laboratório Nacional de Energia e Geologia, Estrada do Paço do Lumiar, 1649-038 Lisboa, Portugal \\ ${ }^{\mathrm{b}}$ Instituto Superior de Agronomia, Universidade de Lisboa, Tapada da Ajuda, 1349-017 Lisboa, Portugal
}

\section{H I G H L I G H T S}

- Jatropha curcas seed cake biomass (JSC) was used as feedstock for bioH $\mathrm{H}_{2}$ production.

- A pure culture of the bacteria Enterobacter aerogenes fermented JSC.

- E. aerogenes was efficient for $2.5-10 \mathrm{gVS}_{\mathrm{JSC}} / \mathrm{L}_{\mathrm{FM}}$ with a maximum of $238.2 \mathrm{~mL} \mathrm{H}_{2} / \mathrm{L}_{\mathrm{FM}}$.

- A new pathway to enhance by-products valorization in biodiesel production chain.

\section{A R T I C L E I N F O}

\section{Article history:}

Received 20 November 2013

Received in revised form 21 February 2014

Accepted 3 September 2014

Available online 19 September 2014

\section{Keywords:}

Biohydrogen

Biodiesel by-product

Biomass pretreatment

Dark fermentation

Jatropha curcas

\begin{abstract}
A B S T R A C T
Hydrogen $\left(\mathrm{H}_{2}\right)$ gas is considered the future energy carrier as a clean fuel. Biological processes to produce hydrogen are very attractive due to less energy expenditures and the possibility to use organic wastes as substrate. In this work, Jatropha curcas L. seed cake (JSC), a solid residue remaining after oil extraction from $J$. curcas seeds for biodiesel production, was used as substrate in a dark fermentation process by a pure strain of the bacteria Enterobacter aerogenes. Batch assays were performed using the substrate (2.5 gVolatile Solid/ $\mathrm{L}_{\mathrm{Fermentation} \mathrm{Medium}}$ ) submitted to thermal pretreatment in an autoclave for two different exposure times (15 and $30 \mathrm{~min}$ ) and the results were compared with the ones obtained when the JSC was used without pretreatment. The best specific biohydrogen production $\left(68.2 \mathrm{~mL} \mathrm{H}_{2} / \mathrm{gVS}_{\mathrm{iJSC}}\right)$ was attained for the conditions of no substrate pretreatment, which is an advantage from the viewpoint of energy saving. In the best conditions, the increase of the initial JSC concentration from 2.5 to $10 \mathrm{gVS} /$ $\mathrm{L}_{\mathrm{FM}}$ led to the increase of the cumulative hydrogen production and to higher $\mathrm{bioH}_{2}$ production rates. However a decrease on the specific $\mathrm{H}_{2}$ production from 68.2 to $23.5 \mathrm{~mL} \mathrm{H}_{2} / \mathrm{gVS}_{\mathrm{iJSC}}$ was observed.
\end{abstract}

(c) 2014 Elsevier Ltd. All rights reserved.

\section{Introduction}

The energy sector is a major contributor to man-made greenhouse gas emissions, therefore, to reach a projected target of $80 \%$ reduction in gas emissions by 2050 will put pressure on existing energy systems [1].

There is a need therefore to explore sources of renewable energy that are viable and able to fulfill human energy demands and contribute towards a decarbonised economy. Hydrogen is considered the "future energy carrier" due to its proprieties as a clean fuel with no $\mathrm{CO}_{2}$ emissions. It is the most promising fuel with most technical, socio-economic and environmental benefits [2]. $\mathrm{H}_{2}$ has the highest energy content per unit weight of any known fuel (142 kJ/g) [2-4]. Among the many hydrogen production processes (conventional and

\footnotetext{
* Corresponding author. Tel.: +351210924600.

E-mail address: paula.marques@lneg.pt (P.A.S.S. Marques).
}

non-conventional), biological methods are known to be the less energy intensive, since most of them can operate at ambient temperature and pressure $[5,6]$. Another advantage is the use of complex organic waste as substrate on bio-hydrogen production fermentative processes, degrading organic compounds and producing clean energy at the same time. In addition, the abundant availability and low cost of the feedstock makes it a very attractive option from both the environmental and economic viewpoint. In this context, the process of dark fermentation to produce $\mathrm{bioH}_{2}$ requires carbohydrate-rich substrates and fermentative bacteria $[7,8]$. In recent years, bioH $_{2}$ production through dark fermentation has received increased attention due to its many advantages, such as the high hydrogen production rates, the potential to convert biomass or bio-wastes into hydrogen, and the feasibility of the effective process design and control [9].

During dark fermentation, $\mathrm{bioH}_{2}$ can be produced by microbial consortia, where the prevailing feedstock are unsterilized waste 